\title{
Distribution of plasma copeptin levels and influence of obesity in children and adolescents
}

\author{
Gerdi Tuli $^{1,2,3}$ - Jessica Munarin ${ }^{1,2} \cdot$ Daniele Tessaris ${ }^{1,2} \cdot$ Silvia Einaudi ${ }^{1,2} \cdot$ Patrizia Matarazzo $^{1,2} \cdot$ Luisa de Sanctis $^{1,2}$
}

Received: 22 April 2020 / Revised: 4 August 2020 / Accepted: 10 August 2020 / Published online: 18 August 2020

(C) The Author(s) 2020

\begin{abstract}
In recent years, a more stable AVP surrogate, called copeptin, has been used as an adjuvant diagnostic tool for dysnatremia in adults and appears to be promising even in the pediatric age. The aim of this study is to present the distribution of plasma copeptin in a large pediatric cohort and to observe the influence of fluid consumption and obesity on its values. A cohort of 128 children and adolescents was divided into two groups on the basis of nocturnal deprivation (group A) or free access to oral fluids in the 6-8 h before blood collection (group B). At all distribution percentiles, copeptin levels were higher $(p<0.0001)$ in group A, as were plasma sodium levels and osmolality $(p=$ 0.02 and $p=0.008$, respectively). The influence of BMI on copeptin levels was investigated by dividing the cohort into nonobese (group C) and obese children and adolescents (group D). Copeptin levels were higher in group D $(p=0.04)$.

Conclusion: The measurement of copeptin could represent a useful tool for the diagnostic pathway of dysnatremic conditions, but its interpretation should take into consideration the state of hydration. Furthermore, it could also be a promising marker for obesity and metabolic syndrome, although this hypothesis needs further studies to be confirmed.
\end{abstract}

What is Known:

- Copeptin use as a diagnostic tool in AVP-related disorders, such as diabetes insipidus or syndrome of inappropriate secretion of antidiuretic hormone, is well established in adults.

- In pediatric age, few studies are available, but the preliminary data, including our previous study, seems to be promising.

What is New:

- In this study, we represent the distribution of copeptin levels in a pediatric cohort and show the significant influence of fluid ingestion on its plasma levels.

- Also BMI seems to be a significant variable on copeptin levels and may be used as an obesity marker in pediatric age.

Keywords Copeptin $\cdot$ Distribution $\cdot$ AVP related disorders $\cdot$ Pediatric age $\cdot$ Obesity

Communicated by Peter de Winter

Gerdi Tuli

gerdi.tuli@unito.it

Jessica Munarin

jessica.munarin@edu.unito.it

Daniele Tessaris

daniele.tessaris@unito.it

Silvia Einaudi

seinaudi@cittadellasalute.to.it
Patrizia Matarazzo

pmatarazzo@cittadellasalute.to.it

Luisa de Sanctis

luisa.desanctis@unito.it

1 Department of Pediatric Endocrinology, Regina Margherita Children's Hospital, Turin, Italy

2 Department of Public Health and Pediatric Sciences, University of Turin, Turin, Italy

3 Turin, Italy 


$\begin{array}{ll}\text { Abbreviations } \\ \text { ADH } & \text { Antidiuretic hormone } \\ \text { AVP } & \text { Arginin-vasopressin } \\ \text { BMI } & \text { Body mass index } \\ \text { CDI } & \text { Central diabetes insipidus } \\ \text { C/RSW } & \text { Cerebral renal salt wasting syndrome } \\ \text { NDI } & \text { Nephrogenic diabetes insipidus } \\ \text { SIADH } & \text { Syndrome of inappropriate antidiuretic } \\ & \text { hormone secretion } \\ \text { WDT } & \text { Water deprivation test }\end{array}$

\section{Introduction}

Arginin-vasopressin (AVP) or antidiuretic hormone (ADH) is one of the main hormones involved in the regulation of water and sodium homeostasis [1-10]; AVP-related disorders are therefore a heterogeneous group of conditions often characterized by severe symptoms, mainly related to dehydration and dysnatremia, even potentially life-threatening if not promptly recognized and adequately treated.

Hyponatremia associated with an inappropriate AVP secretion characterizes the syndrome of inappropriate antidiuretic hormone secretion (SIADH); its diagnosis is often challenging, since its biochemical features overlap with those of the cerebral/renal salt wasting syndrome (C/RSW), a rare and controversial but severe hyponatremic condition found mainly in patients with cerebral tumors [11-16].

Conversely, hypernatremia is the common finding of an insufficient AVP secretion, as observed in central diabetes insipidus (CDI), or an insufficient AVP action despite increased release, in case of AVP receptor resistance (nephrogenic diabetes insipidus, NDI) [17-20].

Plasma concentration of AVP has been classically used in the diagnostic process of all these disorders, but its structural instability, its very short plasma half-life and, last but not least, the long-lasting laboratory processing have limited its use in clinical practice [6, 17-31].

Recent studies have evaluated the usefulness of plasma copeptin in the differential diagnosis of hyponatremic and hypernatremic AVP-related disorders, as it represents a stable and rapidly available surrogate of plasma AVP [32-34]. It has proven to be very useful in the distinction of hypernatremic conditions (such as CDI, NDI, and PP) and less useful in hyponatremia due to the important overlap between SIADH, hyper- or hypovolemic hyponatremia [35-47], a finding already reported also in a small number of pediatric patients [42]. In adults, it seems to be a promising diagnostic tool even after stimulation tests with hypertonic saline or arginine, not yet explored in children [48, 49].

In children, plasma copeptin has been considered as a possible prognostic index of some conditions, such as septic shock, pneumonia, stroke, heart and kidney failure, and traumatic brain injury [50-60]. Higher copeptin levels have also been described in insulin resistant obese children [61]. However, to date few data exist on the distribution of plasma copeptin in the pediatric age and indicate a range between 2.4 and $8.6 \mathrm{pmol} / \mathrm{L}[8,42]$. Our experience on 53 children not affected by AVP-related disorders showed a significant difference in copeptin levels between subjects with free access to fluids and subjects with restriction to fluids for at least $6-8 \mathrm{~h}$ [42].

The purpose of this study is to present the distribution of plasma copeptin in a larger pediatric cohort, also considering fluid intake and body mass index (BMI).

\section{Material and methods}

\section{Study population}

Plasma copeptin levels were measured in 128 children and adolescents without AVP-related disease, who referred to the Department of Pediatric Endocrinology of the Regina Margherita Children's Hospital in Turin in the period July 2016-May 2018.

The reason for hospitalization was a suspected puberty or short stature without hematologic or hormonal abnormalities at baseline evaluation and dynamic hormone assessment; no patient had other comorbidities. Exclusion criteria were the presence of hypo- or hypernatremia, abnormal urinary or plasma osmolality, type I diabetes mellitus, hypo- or hypercalcemia, hypokalemia, hypo- or hyperthyroidism, hypo- or hypercorticism, kidney and heart diseases, recent episodes of nausea or vomiting, infectious diseases, traumatic brain injury, enuresis, and any treatment that interferes with the AVP release system.

Since all subjects had been referred to our department for a fasting blood sample, plasma samples for copeptin investigations were collected early in the morning; based on the retrospective anamnesis of home fluids intake in the 6-8 $\mathrm{h}$ before sample collection, the cohort was then divided into two groups, group A without overnight fluid intake and group B subjects with free access to liquids (which was up to a maximum of $300 \mathrm{ml}$ of water).

The main anthropometric parameters of height, weight, and body mass index (BMI) were detected in the whole study population and allowed the distinction between nonobese (BMI < 95th percentile, group C) and obese children and adolescents $(\mathrm{BMI}>95$ th percentile, group D), accordingly to Cole's BMI percentiles [62].

Before the start of the study, ethical approval was obtained from the Ethics Committee of the City of Health and Science University Hospital of Turin and written informed consent from the families. 


\section{Laboratory samples for plasma copeptin}

Plasma samples for copeptin evaluation were collected into tubes containing ethylenediaminetetraacetic acid (EDTA). The peptide measurement was evaluated concomitantly to serum osmolality by an immunoluminometric assay (BRAHMS CT-proAVP LIA; B.R.A.H.M.S. GmbH, Hennigsdorf Germany) with detection limit $<0.4 \mathrm{pmol} / \mathrm{L}$ and functional assay sensitivity $<1 \mathrm{pmol} / \mathrm{L}$. The percentage of intra- and interassay coefficient of variation $(\mathrm{CV} \%)$ was $<8 \%$ and $<$ $10 \%$, respectively [8].

\section{Statistical analysis and graphs}

Statistical analysis and graphs were performed by Graphpad 7 software (GraphPad Software, La Jolla, CA, USA) using the Student $t$ test for the means comparison. To assess that potential confounders did not affected the results, a multivariate analysis was also performed for BMI and age.

\section{Results}

\section{Distribution of plasma copeptin levels in pediatric age}

In the 128 children and adolescents (median age 8.6 years, range 1.13-17.4 years; 42 boys, 86 girls) with normal plasma sodium and osmolality, the median plasma copeptin level was $7.6 \mathrm{pmol} / \mathrm{L}$ (range $2-14.9 \mathrm{pmol} / \mathrm{L}$ ).

The demographic and biochemical features of the studied population, divided into group A (spontaneous fluids deprivation for at least 6-8 h) and group B (free access to fluids) are represented in Table 1. No significant difference was observed for sex and pubertal stage between the two groups.

The median plasma copeptin level in group A was $10.6 \mathrm{pmol} / \mathrm{l}$ (range 3.3-14.9), while in group B $4.9 \mathrm{pmol} / \mathrm{L}$ (range 2-10.8) $(p<0.0001)$, as shown in Fig. 1.

The median plasma sodium level was $141 \mathrm{mmol} / \mathrm{L}$ (range 138-145) in group A, while $140 \mathrm{mmol} / \mathrm{L}$ (range 134-145) in group $\mathrm{B}(p=0.02)$. A significant difference between the 2 groups was also observed for plasma osmolality (median $285 \mathrm{mOsm} / \mathrm{kg}$ (range 276-291) in group A vs $283.5 \mathrm{mOsm} /$ $\mathrm{kg}$ (range 276-315) in group $\mathrm{B}, p=0.008$ ).

The distribution in percentiles of the plasma copeptin for each group is shown in Table 2 .

No difference was present between males $(n=42)$ and females $(n=86)$, for which median copeptin level was $7.1 \mathrm{pmol} / \mathrm{L}$ (range 3.3-11.2) vs $6.7 \mathrm{pmol} / \mathrm{L}$ (range 2-14.9) respectively $(p=0.61)$.

\section{Copeptin levels in obese children and adolescents}

Biochemical data of nonobese (group C, 102 children, 28 males and 74 females, age 8.35 years, range $1.13-17.4$ years) and obese subjects (group D, 26 children, 14 males and 12 females, age 9.92 years, range 3.35-16.7 years) are represented in Table 3.

Plasma copeptin level was $5.5 \mathrm{pmol} / \mathrm{l}$ (range 2-14.9) in group C, $7.15 \mathrm{pmol} / \mathrm{L}$ (range 3.1-14.2) in group D $(p=0.04)$, as shown in Fig. 2.

The multivariate analysis considering BMI showed no significant differences between the two groups for sex, pubertal stage, fluid state, plasma sodium, and osmolality, but higher age for the obese group $(p=0.02)$. The multivariate analysis considering the age indicates a significant higher proportion of prepubertal females in the nonobese group $(p<0.001)$, but Pearson's correlation coefficient between copeptin levels and age was $0.04(p=0.63)$, and no difference was found in copeptin levels between males and females in the whole studied population $(p=0.43)$, as well as in the obese cohort ( $p=$ $0.78)$.

\section{Discussion}

AVP-related disorders include several clinical conditions that can be life-threatening when hyponatremia or hypernatremia become severe.
Table 1 Demographic and biochemical features of the studied population; group A (fluid fasting for at least $6-8 \mathrm{~h}$ ) and group B (free access to fluids). Median values are reported in parentheses

\begin{tabular}{llll}
\hline & Group A & Group B & $P$ value \\
\hline Whole population $(n)$ & 40 & 88 & \\
Males $(n)$ & 15 & 27 & 0.54 \\
Females $(n)$ & 25 & 61 & \\
Pubertal subjects $(n)$. & 18 & 35 & 0.69 \\
Pre-pubertal subjects $(n)$ & 22 & 53 & 0.61 \\
Age (years) & $8.56(1.13-17.4)$ & $8.66(2.23-16.9)$ & 0.02 \\
Plasma sodium $(\mathrm{mmol} / \mathrm{L})$ & $141(138-145)$ & $140(134-145)$ & 0.008 \\
Plasma osmolality $(\mathrm{mOsm} / \mathrm{kg})$ & $285(276-291)$ & $283.5(276-315)$ & $<0.0001$ \\
Plasma copeptin $(\mathrm{pmol} / \mathrm{L})$ & $10.6(3.3-14.9)$ & $4.9(2-10.8)$ & \\
\hline
\end{tabular}


Fig. 1 Plasma copeptin levels after fluid fasting (group A) and free access to fluids (group B)

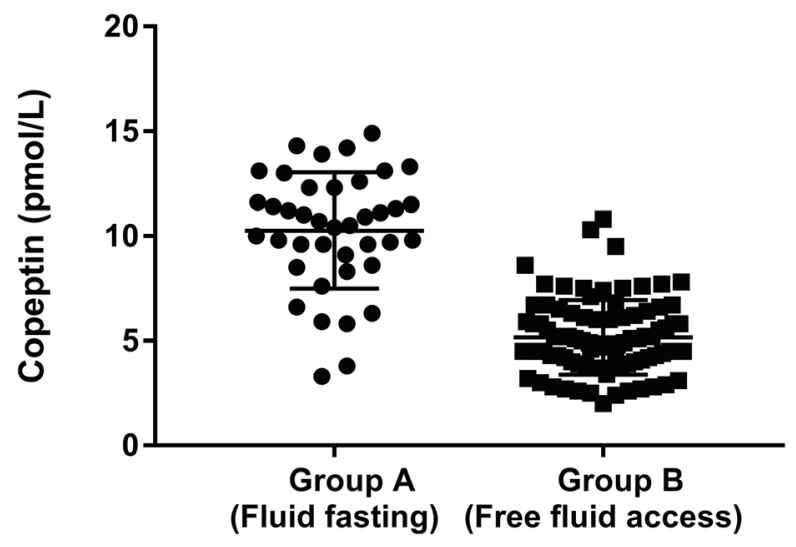

- Group A - Fluid fasting

- Group B - Free fluid access
Therefore, measurement of plasma AVP may be useful in the diagnostic pathway of all these disorders, but its in vitro instability and short half-life have made this investigation almost useless. In recent years, plasma level of an AVP surrogate, called copeptin, has been used thanks to its higher stability and fewer preanalytical procedures [6, 29-32].

Copeptin plasma levels in healthy adults range from 1 to $13 \mathrm{pmol} / \mathrm{L}$ and are very sensitive to osmotic and hemodynamic stimuli similarly to AVP $[48,63,67]$. Males show slightly higher copeptin values with minimal difference in median values; age or circadian rhythm does not seem to interfere nor does food intake or menstrual cycle.

In adults, several studies have evaluated the usefulness of copeptin in the diagnostic pathways of AVP-related diseases, as well as its potential role as prognostic marker in some clinical conditions such as acute myocardial lesions, renal and heart failure, stroke, and sepsis [7, 9, 30-41, 43-47].

Despite many authors have established its usefulness in adult clinical practice, few data have been produced on the value of copeptin as a diagnostic tool for AVP-related diseases in children. Overall, few data exist on the distribution of plasma levels in children and adolescents [42, 50-61]. In a previous paper, we have shown the distribution of copeptin plasma levels in 53 children and adolescents without AVP-related diseases, indicating ranges between 2.4 and $8.6 \mathrm{pmol} / \mathrm{L}$ for the pediatric age [42]; in the present study, we have expanded our cohort of controls without any AVP-related diseases to establish a more defined distribution in the evolutive age.

Plasma copeptin levels were measured in a cohort of 128 children and adolescents who were divided into two groups on the basis of anamnestic fluid ingested in the $6-8 \mathrm{~h}$ prior to collection; the first group included children without fluid intake for at least $6-8 \mathrm{~h}$ before the sample collection, while the second one children with free access to fluids. Copeptin, sodium, and osmolality levels differed significantly in the two groups, although sodium and osmolality were in the normal reference range in both groups. This fact reinforces the knowledge that even small fluctuations of sodium and osmolality within the normal reference range can lead to significant changes in the release of AVP, a peptide that is really sensitive to the hydration status [9, 32-34]. Subjects with free access to fluids showed lower values in all percentiles of the copeptin levels than subjects with fluid deprivation, highlighting that oral fluid intake, even in small quantities, leads to a significant decrease in copeptin values and should be taken into account in the interpretation of its plasma levels. Previous studies have
Table 2 Distribution of plasma copeptin in percentiles

\begin{tabular}{clll}
\hline Percentiles & $\begin{array}{l}\text { Whole population } \\
(\mathrm{pmol} / \mathrm{L})(n=128)\end{array}$ & $\begin{array}{l}\text { Group A (pmol/L) } \\
(n=40)\end{array}$ & $\begin{array}{l}\text { Group B (pmol/L) } \\
(n=88)\end{array}$ \\
\hline 3th & 2.59 & 3.42 & 2.47 \\
5 th & 2.7 & 3.9 & 2.6 \\
10 th & 3.19 & 5.94 & 2.8 \\
25 th & 4.43 & 8.73 & 4 \\
50 th & 5.85 & 10.6 & 4.9 \\
75 th & 9.4 & 12.3 & 6.18 \\
90 th & 11.51 & 13.84 & 7.6 \\
95 th & 13.1 & 14.3 & 8.24 \\
97 th & 13.94 & 14.76 & 9.76 \\
\hline
\end{tabular}


Table 3 Plasma sodium, osmolality and copeptin levels in not obese and obese children. Median values are reported in parentheses

\begin{tabular}{|c|c|c|c|}
\hline & Group C (not obese) & Group D (obese) & $P$ value \\
\hline Whole population $(n)$ & 102 & 26 & - \\
\hline $\begin{array}{l}\text { Males }(n) \\
\text { Females }(n)\end{array}$ & $\begin{array}{l}28 \\
74\end{array}$ & $\begin{array}{l}14 \\
12\end{array}$ & 0.26 \\
\hline $\begin{array}{l}\text { Pubertal subjects }(n) \\
\text { Prepubertal subjects }(n)\end{array}$ & $\begin{array}{l}38 \\
64\end{array}$ & $\begin{array}{l}15 \\
11\end{array}$ & 0.54 \\
\hline $\begin{array}{l}\text { Spontaneous fluids deprivation }(n) \\
\text { Fluids restriction }(n)\end{array}$ & $\begin{array}{l}29 \\
73\end{array}$ & $\begin{array}{l}11 \\
15\end{array}$ & 0.4 \\
\hline Age (years) & $8.35(1.13-17.4)$ & $9.92(3.35-16.7)$ & 0.02 \\
\hline Plasma sodium $(\mathrm{mmol} / \mathrm{L})$ & $141(134-145)$ & $140.5(138-145)$ & 0.44 \\
\hline Plasma osmolality (mOsm/kg) & $284(276-315)$ & $284(276-297)$ & 0.47 \\
\hline Plasma copeptin (pmol/L) & $5.5(2-14.9)$ & $7.15(3.1-14.2)$ & 0.04 \\
\hline
\end{tabular}

indicated mean normal copeptin levels similar to those reported here, without defining a percentile distribution $[50,52,54$, 58].

We are aware that a major limitation of this study is represented by the size of the cohort which allowed us to indicate only the distribution, as it should be much larger to obtain true reference percentiles. Another limitation can be represented by the evaluation of the hydration state at the time of the sample collection, since it is known that the copeptin is very sensitive to the variation of even small quantities of liquids, both administered intravenously and ingested orally. So we decided to divide the series of cases into subjects without any fluid intake during the night preceding the collection and subjects who had taken it, even if in small quantities.

The relationship between copeptin levels and obesity [64-69], as well as its association with metabolic and cardiovascular risk factors, has already been explored in adulthood and in animal models. A positive correlation between plasma copeptin levels and metabolic syndrome parameters had already been described also in children, and higher copeptin levels have been described in obese children $[60,61]$. Our data, within a cohort of subjects with normal serum sodium and osmolality, indicate significantly higher copeptin levels in obese children than in the nonobese counterpart. The significant differences in the age of the two groups could be explained by the fact that the onset of obesity occurs mainly in adolescence, even if copeptin levels did not show any correlation to age nor difference for sex. Therefore, plasma copeptin levels might be an important indicator of BMIrelated glucose metabolism dysfunction, although further studies with larger cohorts and analysis of metabolic parameters are needed to confirm this hypothesis.

\section{Conclusion}

The present study further strengthens the fact that plasma copeptin level could be regarded as a useful indicator of AVP system function and water and sodium homeostasis; it should therefore be included in the diagnostic pathway of all hypernatremic and hyponatremic conditions for a more correct diagnosis and consequently an appropriate treatment choice.
Fig. 2 Plasma copeptin levels in non-obese children (group C) and obese children (group D)

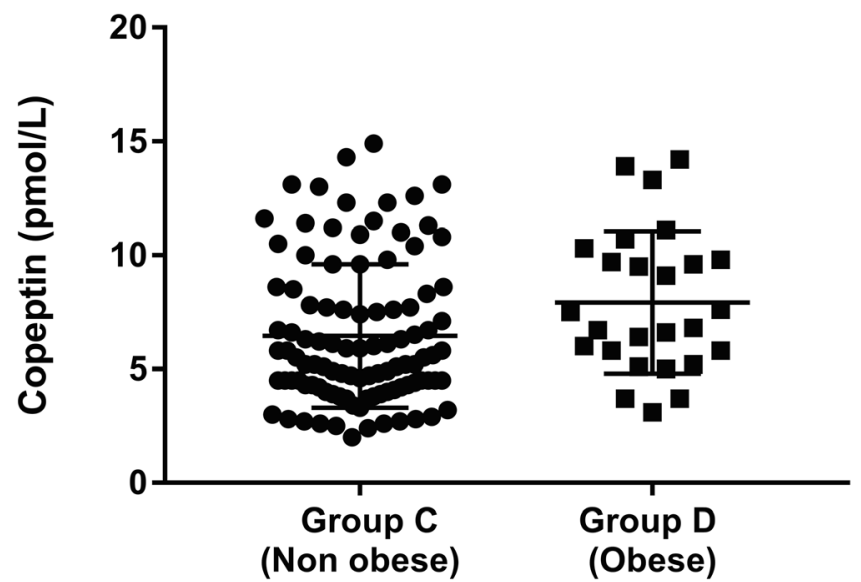

- Group C - Non obese

- Group D - Obese 
It is undoubtedly a marker very sensitive to plasma sodium and osmolality variations, as well as to fluids administered orally or intravenously, which therefore must be considered in the interpretation of the results.

In the present study, we presented the distribution of plasma copeptin in percentiles in a population of children without disturbances of the AVP release system, in order to have normal copeptin values as potential reference in the suspicion of AVP release disorders.

Considering the anthropometric variables in our control population, we can postulate that copeptin might also be a promising marker for other conditions such obesity and the metabolic syndrome in children and adolescents, although this hypothesis needs further studies to be confirmed.

Authors' contribution All authors contributed to the conception and design of the study. The preparation of the material, the collection and analysis of the data were performed by G.T. and J.M. The first draft of the manuscript was written by G.T., and all authors added comments to the first and subsequent versions of the manuscript. D.T. and S.E performed the statistical analysis. P.M. and L.d.S. have carried out the final revision of the manuscript. All authors read and approved the final manuscript.

Funding Information Open access funding provided by Università degli Studi di Torino within the CRUI-CARE Agreement.

\section{Compliance with ethical statements}

Conflict of interest The authors declare that they have no conflict of interest.

Ethical approval This article does not contain any studies with human participants or animals performed by any of the authors.

Informed consent Informed consent was obtained from all parents of individual participants included in the study.

Open Access This article is licensed under a Creative Commons Attribution 4.0 International License, which permits use, sharing, adaptation, distribution and reproduction in any medium or format, as long as you give appropriate credit to the original author(s) and the source, provide a link to the Creative Commons licence, and indicate if changes were made. The images or other third party material in this article are included in the article's Creative Commons licence, unless indicated otherwise in a credit line to the material. If material is not included in the article's Creative Commons licence and your intended use is not permitted by statutory regulation or exceeds the permitted use, you will need to obtain permission directly from the copyright holder. To view a copy of this licence, visit http://creativecommons.org/licenses/by/4.0/.

\section{References}

1. Jain A (2015) Body fluid composition. Pediatr Rev 36(4):141-150

2. Ruth JL, Wassner SJ (2006) Body fluid composition: salt and water. Pediatr Rev 27(5):181-187
3. Ranadive SA, Rosenthal SM (2011) Pediatric disorders of water balance. Pediatr Clin N Am 58(5):1271-1280

4. Gizowski C, Bourque CW (2018) The neural basis of homeostatic and anticipatory thirst. Nat Rev Nephrol 14(1):11-25

5. Zimmerman CA, Leib DE, Knight ZA (2017) Neural circuits underlying thirst and fluid homeostasis. Nat Rev Neurosci 18(8):459469

6. Bankir L, Bichet DG, Morgenthaler NG (2017) Vasopressin: physiology, assessment and osmosensation. J Intern Med 282(4):284297

7. Rotondo F, Butz H, Syro LV, Yousef GM, Di Ieva A, Restrepo LM, Quintanar-Stephano A, Berczi I, Kovacs K (2016) Arginine vasopressin (AVP): a review of its historical perspectives, current research and multifunctional role in the hypothalamo-hypophysial system. Pituitary 19(4):345-355

8. Bolignano D, Cabassi A, Fiaccadori E, Ghigo E, Pasquali R, Peracino A, Peri A, Plebani M, Santoro A, Settanni F, Zoccali C (2014) Copeptin (CTproAVP), a new tool for understanding the role of vasopressin in pathophysiology. Clin Chem Lab Med 52(10):1447-1456

9. Morgenthaler NG (2014) Copeptin - biochemistry and clinical diagnostic. UNI-MED-Verlag, Bremen

10. Holmes CL, Landry DW, Granton JT (2003) Science review: vasopressin and the cardiovascular system part 1- receptor physiology. Crit Care 7(6):427-434

11. Cuesta M, Garrahy A, Thompson CJ (2016) SIAD: practical reccomendations for diagnosis and management. J Endocrinol Investig 39(9):991-1001

12. Oh JY, Shin JI (2015) Syndrome of inappropriate antidiuretic hormone secretion and cerebrla/renal salt wasting syndrome: similarities and differences. Front Pediatr. https://doi.org/10.3389/fped. 2014.00146

13. Cuesta M, Thompson CJ (2016) The syndrome of inappropriate antidiuresis (SIAD). Best Pract Res Clin Endocrinol Metab 30(2): $175-187$

14. Hardesty DA, Kilbaugh TJ, Storm PB (2012) Cerebral salt wasting syndrome in post-operative pediatric brain tumor patients. 17(3): 382-387

15. González Briceño L, Grill J, Bourdeaut F, Doz F, Beltrand J, Benabbad I, Brugières L, Dufour C, Valteau-Couanet D, Guerrini-Rousseau L, Aerts I, Orbach D, Alapetite C, SamaraBoustani D, Pinto G, Simon A, Touraine P, Sainte-Rose C, Zerah M, Puget S, Elie C, Polak M (2014) Water and electrolyte disorders at long term post-treatment follow-up in paediatric patients with suprasellar tumours include unexpected persistent cerebral saltwasting syndrome. Horm Res Paediatr 82(6):364-371

16. Bettinelli A, Longoni L, Tammaro F, Faré PB, Garzoni L, Bianchetti MG (2012) Renal salt-wasting sindrome in children with intracranial disorders. Pediatr Nephrol 27(5):733-739

17. Dabrowski E, Kadakia R, Zimmerman D (2016) Diabetes insipidus in infants and children. Best Pract Res Clin Endocrinol Metab 30(2):317-328

18. Patti G, Ibba A, Morana G, Napoli F, Fava D, di Iorgi N, Maghnie M (2020) Central diabetes insipidus. Diagnosis and management. Best Pract Res Clin Endocrinol Metab. https://doi.org/10.1016/j. beem. 2020

19. Bockenhauer D, Bichet DG (2017) Nephrogenic diabetes insipidus. Curr Opin Pediatr 29(2):199-205

20. Sands JM, Klein JD (2016) Physiological insights into novel therapies for nephrogenic diabetes insipidus. Am J Physiol Renal Physiol 311(6):F1149-F1152. https://doi.org/10.1152/ajprenal. 00418.2016

21. Djermane A, Elmaleh M, Simon D, Poidvin A, Carel JC, Léger J (2016) Central diabetes insipidus in infancy with or without hypothalamic adipsic hypernatremia syndrome: early identification and outcome. J Clin Endocrinol Metab 101(2):635-643 
22. Wong LM, Man SS (2012) Water deprivation test in children with polyuria. J Pediatr Endocrinol Metab 25(9-10):869-874

23. Di Iorgi N, Allegri AE, Napoli F, Calcagno A, Calandra E, Fratangeli N, Vannati M, Rossi A, Bagnasco F, Haupt R, Maghnie M (2014) Central diabetes insipidus in children and young adults: etiological diagnosis and long-term outcome of idiopathic causes. J Clin Endocrinol Metab 99(4):1264-1272

24. Robertson GL (2016) Diabetes insipidus: differential diagnosis and management. Best Pract Res Clin Endocrinol Metab 30(2):205-218

25. Kalra S, Zargar AH, Jain SM, Sethi B, Chowdhury S, Singh AK, Thomas N, Unnikrishnan AG, Thakkar PB, Malve H (2016) Diabetes insipidus: the other diabetes. Indian J Endocrinol Metab 20(1):9-21

26. Edate S, Albanese A (2015) Mangement of electrolyte and fluid disorders after brain surgery for pituitary/suprasellar tumours. Horm Res Paediatr 83(5):293-301

27. Matarazzo P, Genitori L, Lala R, Andreo M, Grossetti R, De Sanctis C (2004) Endocrine 231 function and water metabolism in children and adolescents with treated intra/parasellar tumours. J Pediatr Endocrinol Metab 17(11):1487-1495

28. Matarazzo P, Tuli G, Verna F, Tessaris D, Fiore L, Mussa A, Repici M, Lala R (2010) Management of sodium metabolism derangements in children treated for hypothalamic-hypophyseal tumours. J. Pediatr Biochem 4:289-296

29. Bichet DG (2019) Regulation of thirst and vasopressin release. Annu Rev Physiol 81:359-373

30. Quintana DS, Westlye LT, Smerud KT, Mahmoud RA, Djupesland PG, Andreassen OA (2017) Reliability of basal plasma vasopressin concentrations in healthy male adults. Acta Neuropsychiatr 29(5): 315-321

31. Guelinckx I, Vecchio M, Perrier ET, Lemetais G (2016) Fluid intake and vasopressin: connecting the dots. Ann Nutr Metab 68(Suppl 2):6-11

32. Morgenthaler NG, Struck J, Alonso C, Bergmann A (2006) Assay for the measurement of copeptin, a stable peptide derived from the precursor of vasopressin. Clin Chem 52(1):112-119

33. Balanescu S, Kopp P, Gaskill MB, Morgenthaler NG, Schindler C, Rutishauser J (2011) Correlation of plasma copeptin and vasopressin concentrations in hypo-, iso-, and hyperosmolar states. J Clin Endocrinol Metab 96(4):1046-1052

34. Beglinger S, Drewe J, Christ-Crain M (2017) The circadian rhythm of copeptin, the C-terminal portion of arginine vasopressin. J Biomark 2017:1-5. https://doi.org/10.1155/2017/4737082

35. Christ-Crain M, Fenske W (2016) Copeptin in the diagnosis of vasopressin-dependent disorders of fluid homeostasis. Nat Rev Endocrinol 12(3):168-176

36. Fenske W, Störk S, Blechschmidt A, Maier SG, Morgenthaler NG, Allolio B (2009) Copeptin in the differential diagnosis of hyponatremia. J Clin Endocrinol Metab 94(1):123-129

37. Boursier G, Alméras M, Buthiau D, Jugant S, Daubin D, Kuster N, Dupuy AM, Ribstein J, Klouche K, Cristol JP (2015) CT-pro-AVP as a tool for assessment of intravascular volume depletion in severe hyponatremia. Clin Biochem 48(10-11):640-645

38. Wuttke A, Dixit KC, Szinnai GG, Werth SC, Haagen U, ChristCrain M, Morgenthaler NG, Brabant G (2013) Copeptin as a marker for arginine-vasopressin/antidiuretic hormone secretion in the diagnosis of paraneoplastic syndrome of inappropriate $\mathrm{ADH}$ secretion. Endocr 44:744-749

39. Fenske WK, Christ-Crain M, Hörning A, Simet J, Szinnai G, Fassnacht M, Rutishauser J, Bichet DG, Störk S, Allolio B (2014) A copeptin-based classification of the osmoregolatory defects in the syndrome of inappropriate antidiuresis. J Am Soc Nephrol 25(10): 2376-2383

40. Nigro N, Winzeler B, Suter-Widmer I, Schuetz P, Arici B, Bally M, Blum CA, Nickel CH, Bingisser R, Bock A, Huber A, Müller B, Christ-Crain M (2017) Evaluation of copeptin and commonly used laboratory parameters for the differential diagnosis of profound hyponatraemia in hospitalized patients: 'The Co-MED Study'. Clin Endocrinol 86:456-462

41. Fenske W, Sandner B, Christ-Crain M (2016) A copeptin-based classification of the osmoregolatory defects in the syndrome of inappropriate antidiuresis. Best Pract Res Clin Endocrinol Metab 30(2):219-233

42. Tuli G, Tessaris D, Einaudi S, Matarazzo P, De Sanctis L (2018) Copeptin role in polyuria-polydipsia syndrome differential diagnosis and reference range in paediatric age. Clin Endocrinol 88(6): 873-879

43. Fenske W, Quinkler M, Lorenz D, Zopf K, Haagen U, Papassotiriou J, Pfeiffer AF, Fassnacht M, Störk S, Allolio B (2011) Copeptin in the differential diagnosis of the polydipsiapolyuria syndrome. Revisiting the direct and indirect water deprivation tests. J Clin Endocrinol Metab 96(5):1506-1515

44. Timper K, Fenske W, Kühn F, Frech N, Arici B, Rutishauser J, Kopp P, Allolio B, Stettler C, Müller B, Katan M, Christ-Crain M (2015) Diagnostic accuracy of copeptin in the differential diagnosis of the polyuria-polydipsia syndrome: a prospective multicenter study. J Clin Endocrinol Metab 100(6):2268-2274

45. Timper K, Fenske WK, Katan M, Kühn F, Arici B, Schütz P, Frech N, Rutishauser J, Kopp P, Stettler C, Müller B, Christ-Crain M (2014) Copeptin in the diagnosis and differential diagnosis of diabetes insipidus - the 'Cosip-Study'. Exp Clin Endocrinol Diabetes. https://doi.org/10.1055/s-0034-1372046

46. Winzeler B, Zweifel C, Nigro N, Arici B, Bally M, Schuetz P, Blum CA, Kelly C, Berkmann S, Huber A, Gentili F, Zadeh G, Landolt H, Mariani L, Müller B, Christ-Crain M (2015) Postoperative copeptin concentration predicts diabetes insipidus after pituitary surgery. $\mathrm{J}$ Clin Endocrinol Metab 100(6):2275-2282

47. de Fost M, Oussada SM, Linthorst GE, Serlie MJ, Soeters MR, De Vries JH, Bisschop PH, Fliers E (2015) The water deprivation test and a potential role for the arginine vasopressin precursor copeptin to differentiate diabetes insipidus from primary polydipsia. Endocr Conn 4:86-91

48. Fenske W, Refardt J, Chifu I, Schnyder I, Winzeler B, Drummond J, Ribeiro-Oliveira A Jr, Drescher T, Bilz S, Vogt DR, Malzahn U, Kroiss M, Christ E, Henzen C, Fischli S, Tönjes A, Mueller B, Schopohl J, Flitsch J, Brabant G, Fassnacht M, Christ-Crain M (2018) A copeptin-based approach in the diagnosis of diabetes Insipidus. N Engl J Med 379(5):428-439

49. Winzeler B, Cesana-Nigro N, Refardt J, Vogt DR, Imber C, Morin B, Popovic M, Steinmetz M, Sailer CO, Szinnai G, Chifu I, Fassnacht M, Christ-Crain M (2019) Arginine-stimulated copeptin measurements in the differential diagnosis of diabetes insipidus: a prospective diagnostic study. Lancet 394(10198):587-595

50. Du JM, Sang G, Jiang CM, He XJ, Han Y (2013) Relationship between 288 plasma copeptin levels and complications of community-acquired pneumonia in preschool children. Peptides 45:61-65

51. Wrotek A, Jackowska T, Pawlik K (2015) Sodium and copeptin levels in children with community acquired pneumonia. Adv Exp Med Biol 835:31-36

52. Stöcklin B, Fouzas S, Schillinger P, Cayir S, Skendaj R, Ramser M, Weber P, Wellmann S (2015) Copeptin as a serum biomarker of febrile seizures. PLoS One 10:e0124663. https://doi.org/10.1371/ journal.pone. 0124663

53. Mastropietro CW, Mahan M, Valentine KM, Clark JA, Hines PC, Walters HL 3rd, Delius RE, Sarnaik AP, Rossi NF (2012) Copeptin as a marker of relative arginine vasopressin deficiency after pediatric cardiac surgery. Intensive Care Med 38(12):2047-2054

54. Lin C, Wang N, Shen ZP, Zhao ZY (2013) Plasma copeptin concentration and outcome after pediatric traumatic brain injury. Peptides 42:43-47 
55. Nalbantoğlu B, Yazıcı CM, Nalbantoğlu A, Güzel S, Topçu B, Güzel EÇ, Donma MM, Özdilek B, Mintaş NE (2013) Copeptin as a novel biomarker in nocturnal enuresis. Urology 82(5):1120 1123

56. Coelho R, Levandowski ML, Mansur RB, da Cunha GR, Asevedo E, Zugman A, Salum GA, Gadelha A, Pan PM, Rizzo LB, Manfro G, Mari JJ, Rohde LA, Miguel EC, Bressan RA, Brietzke E, GrassiOliveira R (2016) Serum copeptin in children exposed to maltreatment. Psychiatry Clin Neurosci 70(10):434-441

57. Lee JH, Chan YH, Lai OF, Puthucheary J (2013) Vasopressin and copeptin levels in children with sepsis and septic shock. Intensive Care Med 39(4):747-753

58. Schiel R, Perenthaler TJ, Steveling A, Stein G (2016) Plasma copeptin in children and adolescents with type 1 diabetes mellitus in comparison to healthy controls. Diabetes Res Clin Pract 118: 156-161

59. Zhao J, Du S, Yang J, Lin J, Tang C, Du J, Jin H (2014) Usefulness of plasma copeptin as a biomarker to predict the therapeutic effectiveness of metoprolol for postural tachycardia syndrome in children. Am J Cardiol 114(4):601-605

60. Tenderenda-Banasiuk E, Wasilewska A, Filonowicz R, Jakubowska U, Waszkiewicz-Stojda M (2014) Serum copeptin levels in adolescents with primary hypertension. Pediatr Nephrol 29(3):423-429

61. Rothermel J, Kulle A, Holterhus PM, Toschke C, Lass N, Reinehr T (2016) Copeptin in obese children and adolescents: relationships to body massindex, cortisol and gender. Clin Endocrinol 85(6):868873
62. Cole TJ, Lobstein T (2012) Extended international (IOTF) body mass index cut-offs for thinness, overweight and obesity. Pediatr Obes 7(4):284-294

63. Refardt J, Winzeler B, Christ-Crain M (2018) Copeptin and its role in the diagnosis 317 of diabetes insipidus and the syndrome of inappropriate antidiuresis. Clin Endocrinol 91(1):22-32

64. Enhorning S, Struck J, Wirfalt E, Hedblad B, Morgenthaler NG, Melander O (2011) Plasma Copeptin, a unifying factor behind the metabolic syndrome. J Clin Endocrinol Metab 96(7):E1065-E1072

65. Enhörning S, Bankir L, Bouby N, Struck J, Hedblad B, Persson M, Morgenthaler NG, Nilsson PM, Melander O (2013) Copeptin, a marker of vasopressin, in abdominal obesity, diabetes and microalbuminuria: the prospective Malmö Diet and Cancer Study cardiovascular cohort. Int J Obes 37(4):598-603

66. Enhörning S, Sjögren M, Hedblad B, Nilsson PM, Struck J, Melander O (2016) Genetic vasopressin 1b receptor variance in overweight and diabetes mellitus. Eur J Endocrinol 174(1):69-75

67. Nakamura K, Velho G, Bouby N (2017) Vasopressin and metabolic disorders: translation from experimental models to clinical use. J Intern Med 282(4):298-309

68. Taskin MI, Bulbul E, Adali E, Hismiogulları AA, Inceboz U (2015) Circulating levels of obestatin and copeptin in obese and non-obese women with polycystic ovary syndrome. Eur J Obstet Gynecol Reprod Biol 189:19-23

69. Christ-Crain M (2019) Vasopressin and copeptin in health and disease. Rev Endocr Metab Dis 20:283-294

Publisher's note Springer Nature remains neutral with regard to jurisdictional claims in published maps and institutional affiliations. 